\title{
Layanan Bimbingan Kelompok Melalui Teknik Sosiodrama dalam Mengurangi Kecanduan Gadget pada Siswa
}

\author{
Lina Ayu Ashari Harahap ${ }^{1}$, Ika Sandra Dewi ${ }^{2}$ \\ ${ }_{12}$ Program Studi Bimbingan Konseling Universitas Muslim Nusantara Al-Washliyah, Sumatra Utara \\ Indonesia \\ 1linaayuashari99@gmail.com, 2 ikasandradewi@umnaw.ac.id
}

First received:

10 September 2021
Revised:

05 Nopember 2021
Final Accepted:

25 Desember 2021

\begin{abstract}
Abstrak
Penelitian ini bertujuan untuk: (1) melihat adakah pengaruh layanan bimbingan kelompok melalui teknik sosiodrama dalam mengurangi kecanduan gadget pada siswa di madrasah Aliyah Al-Wasliyah Tembung; (2) melihat bagaimana pengaruh layanan bimbingan kelompok melalui teknik sosiodrama dalam mengurangi kecanduan gadget pada siswa di madrasah Aliyah Al-Wasliyah Tembung. Penelitian ini akan melakukan pengambilan sekitar 10 (Sepuluh) anak yang memiliki kecanduan gadget yang tingg kemudian diberikan layanan bimbingan kelompok teknik sosiodrama. Pengambilan sampel penelitian berdasarkan siswa yang memiliki skor kecanduan Gadget yang paling tinggi. Pengumpulan data penelitian ini dikumpulkan dengan menggunakan instrumen penelitian berupa skala kecanduan gadget. Validitas instrument menggunakan rumus product moment dan reabilitas menggunakan rumus alfa cronbach. Analisis data menggunakan rumus t-test. Hasil penelitian menunjukkan beberapa kesimpulan yakni: (1) Hasil data penelitian menunjukkan adanya hubungan yang signifikan antara bimbingan kelompok teknik sosiodrama dengan kecanduan gadget. $\mathrm{t}$ (hitung) $=19,561$ kemudian dibandingkan dengan $\mathrm{t}$ (table) $=2,1009022$; (2) Penurunan terlihat melalui hasil kegiatan dengan data pada Pre-Test ditemukan 3 orang masuk pada kategorisasi Sangat tinggi kecanduan Gadget dan 7 orang masuk pada kategorisasi Tinggi kecanduan Gadget. Sementara pada data Post-Test setelah melakukan layanan bimbingan kelompok dengan teknik sosiodrama ditemukan penurunan angka kecanduan dengan 2 orang masuk kategorisasi Sangat Rendah kecanduan Gadget, 7 orang masuk kategorisasi Rendah kecanduan Gadget dan 1 orang masuk kategorisasi Sedang kecanduan Gadget.
\end{abstract}

Kata Kunci: Sosiodrama, Kecanduan, Gadget

\begin{abstract}
Abstrac
This study aims to: (1) see whether there is an effect of group guidance services through sociodrama techniques in reducing gadget addiction in students at the Aliyah Al-Wasliyah Tembung madrasa; (2) see how the influence of group guidance services through sociodrama techniques in reducing gadget addiction in students at the Aliyah Al-Wasliyah Tembung madrasa. This study will take about 10 (Ten) children who have a high gadget addiction and then be given sociodrama technique group guidance services. The research sample was taken based on the students who had the highest gadget addiction scores. This research data collection was collected using a research instrument in the form of a gadget addiction scale. The validity of the instrument uses the product moment formula and the reliability uses the Cronbach alpha formula. Data analysis used the t-test formula. The results showed several conclusions, namely: (1) The results of the research data showed a significant relationship between the sociodrama technique group guidance and gadget addiction. $t$ (count) $=19.561$ then compared with $t$ (table) $=2.1009022$; (2) The decrease is seen through the results of
\end{abstract}


activities with data on the Pre-Test found that 3 people fall into the very high category of Gadget addiction and 7 people fall into the High category of Gadget addiction. Meanwhile, in the Post-Test data, after conducting group guidance services using sociodrama techniques, it was found that there was a decrease in the number of addictions with 2 people categorized as Very Low with Gadget addiction, 7 people in the Low category for Gadget addiction and 1 person in the Medium category with Gadget addiction.

Keyword: Sociodrama Technique, Addiction, Gadget

\section{PENDAHULUAN}

Di zaman yang serba canggih seperti ini kehadiran gadget telah menjadi sebuah kebutuhan utama baik dari anak-anak maupun orang dewasa. Gadget atau Gadget tidak hanya sebagai alat untuk berkomunikasi namun juga dapat membantu mempermudah melakukan aktivitas-aktivitas lainnya. Gadget adalah istilah yang berasal dari bahasa inggris yang diartikan sebagai perangkat elektronik kecil yang memiliki fungsi khusus (Istiarni \& Triningsih, 2018.

Iswidhamanjaya (2014) menjelaskan beberapa hal yang dapat dilakukan orang tua untuk mengawasi penggunaan gadget diantaranya; (1) Menguasai teknologi gadget; (2) Memberikan ponsel sesuai kebutuhan dari anak; (3) memberikan batasan waktu penggunaan; (4) Memasang password pada gadget; (5) Membatasi Aplikasi yang tidak penting; (6) memberikan batasan aplikasi berbayar; (7) Memeriksa history; (8) Jauhkan pornografi pada anak; (9) Mengenal game yang dimainkan oleh anak; (10) Menjalin pertemanan di media sosial antara orang tua dan anak; (11) Bersosialisasi dengan lebih bijak dan aman; (12) Memaksimalkan pengamanan akun.

Pecandu gadget pada tahun 2014 di Indonesia semakin meningkat dari 1,4 miliar pengguna gadget 176 juta orang diantaranya adalah pecandu gadget, angka ini meningkat 123\% dibanding tahun 2013 yang hanya 79 juta orang (Purwanto, Atina, \& Desylawati, 2017). Pengguna aplikasi game online melalui gadget dan telah mengalami ketergantungan gadget di Indonesia tahun 2017 terindikasi sejumlah 6 juta dengan pengguna remaja kurang lebih 40\% (Sari \& Prajayanti, 2017). Tingginya tingkat penggunaan gadget sangat berpengaruh besar terhadap perkembangan siswa khususnya pada perkembangan sosialnya (Yulia,2012; Armayanti, 2013; Darnoto, 2016; Faiz, 2018).

Tujuan bimbingan kelompok menurut Susanto (2018:255) yaitu untuk meningkatkan pemahaman tentang kenyataan, aturan-aturan dalam kehidupan, dan cara-cara yang dapat dilakukan untuk menyelesaikan tugas, serta meraih masa depan dalam studi, karier, ataupun kehidupan. Artinya, bimbingan kelompok dilaksanakan sebagai sarana untuk memperdalam pemahaman siswa agar dapat menjalani kehidupan dengan baik. Salah satu teknik bimbingan kelompok yang dapat diterapkan adalah teknik sodiodrama karena dari sosiodrama anak didik dapat langsung mengurangi hal-hal negative mengenai gadget dan bahkan dapat merasakan langsung ketika bermain sosiodrama.

Salah satu layanan yang dapat diberikan untuk mengurangi kecanduan gadget pada siswa adalah pemberian layanan bimbingan kelompok dengan teknik sosiodrama karena dari sosiodrama anak didik dapat langsung mengurangi hal-hal negative mengenai gadget dan 
bahkan dapat merasakan langsung ketika bermain sosiodrama (Rochmawati, 2012; Rosy, 2017). Seperti problema yang dihadapi guru bimbingan Konseling di madrasah Aliyah Al-Wasliyah Tembung, memunculkan asumsi atau anggapan dasar yakni bimbingan kelompok teknik sosiodrama merupakan salah satu layanan yang dapat mengurangi kecanduan gadget

\section{METODE}

Adapun desain yang digunakan dalam penelitian ini dapat di lihat dibawah ini;

\section{$\mathrm{O}_{1 \times} \mathrm{O}_{2}$ \\ $\mathrm{O}_{1}$ : Pre-test \\ $\mathrm{X}$ : Perlakuan/treatment \\ $\mathrm{O}_{2}$ : Post-test}

Di dalam desain ini penelitian dilakukan sebanyak dua kali yaitu sebelum eksperimen dan sesudah eksperimen. Penelitian yang dilakukan sebelum eksperimen $\left(\mathrm{O}_{1}\right)$ disebut pre-test, setelah eksperimen $\left(\mathrm{O}_{2}\right)$ disebut post-test.

Adapun populasi dari penelitian ini adalah siswa kelas XI Madrasah Aliyah AlWasliyah Tembung. Siswa kelas XI dipilih dikarenakan sarana dari pihak sekolah melalui guru BK. Siswa kelas XI dianggap guru bimbingan konseling yang memiliki tingkat kecanduan gadget lebih tinggi dibanding kelas $X$ dan XII. Jumlah siswa kelas XI adalah 50 orang. Sampel pada penelitian ini menggunakan teknik purposive sampling. Sugiyono (2019:133) menyatakan bahwa purposive sampel adalah teknik penelitian dengan cara menetapkan ciri-ciri khusus yang disesuaikan dengan tujuan penelitian sehingga diharapkan dapat menjawab permasalahan penelitian. Jumlah siswa yang akan diambil sebagai sampel adalah 10 orang dengan mengacu pada pendapat Prayitno (2017:136) pembentukan kelompok pada bimbingan kelompok terdiri dari 8-10 peserta. Jadi sampel dalam penelitian ini berjumlah 8-10 orang siswa yang memiliki tingkat kecanduan gadget yang tinggi. Siswa dipilih berdasarkan hasil pengolahan data instrumen kecanduan gadget pada siswa yang nantinya akan disebarkan. Pada penelitian ini instrument yang digunakan iayalah Instrument kecanduan Gadget (Yuwanto, 2012) sebanyak 40 item pernyataan dengan $r=0,94$. Adapun pengujian hipotesis menggunakan uji $t$ sample berkorelasi.

\section{HASIL}

Madrasah Aliyah Swasta (MAS) AlWashliyah 22 Tembung juga berperan aktif dalam upaya menciptakan generasi agama dan bangsa yang memiliki intelektual yang baik, emosional yang terarah serta Spiritual yang istiqomah. Dalam hal pencapaian tujuan di atas, maka Madrasah Aliyah Swasta (MAS) Al - Washliyah Tembung menuangkannya dalam Visi yakni; "Mewujudkan insan pembangunan yang dapat membangun dirinya sendiri dan masyarakat lainnya serta sama bertanggungjawab atas pembangunan bangsa dan Negara Republik Indonesia berdasarkan Tujuan Pendidikan Nasional dan Tujuan Pendidikan AlWashliyah".

Madrasah Aliyah Swasta (MAS) AlWashliyah 22 Tembung merupakan lembaga pendidikan formal yang berorientasi kepada pendidikan agama dan umum, artinya kegiatan pembelajaran yang dilaksanakan di madrasah ini berfokus kepada pendidikan agama yang terintegrasi dengan pendidikan umum. Seperti umumnya lembaga pendidikan di tiap sekolah yang ada, tentunya memiliki profil atau gambaran umum tentang sekolah itu, sehingga dengan melihat profilnya kita sudah tahu bagaimana keadaan di sekolah/madrasah tersebut. 
Senada dengan hal ini, Madrasah Aliyah Swasta (MAS) Al-Washliyah 22 Tembung ini juga memiliki profil yang menjadi identitas sekolah.

Pemberi layanan

Perencanaan pemberian layanan meliputi penyusunan instrumen kecanduan Gadget, dan penjadwalan waktu layanan. Peneliti juga mengajukan permohonan izin penelitian dan mempersiapkan instrumen utama penelitian dan perlengkapan pendukung lain yang dibutuhkan pada saat pelaksanaan penelitian.

Selanjutnya, peneliti bersama guru BK dan perwakilan siswa berdiskusi bersama membahas waktu dan tempat pelaksanaan kegiatan dengan durasi pertemuan yakni 90 menit. Peneliti dan guru BK mengawali kegiatan dengan perkenalan diri dan membangun komunikasi yang baik dengan siswa. Peneliti mejelaskan tujuan dan agenda pelaksanaan kegiatan secara lisan kemudian memaparkan materi kegiatan sosiodrama.

Pada 15 menit awal kegiatan, siswa cenderung masih terlihat malu-malu dalam memainkan peran tokoh tertentu. Terlihat siswa seperti tegang dalam menjalankan yang dialami siswa tapi perlahan demi perlahan siswa lebih bisa merasa santai dan dapat mendalami peran yang dimainkan. Setelah pementasan sosiodrama peneliti dan guru BK selanjutnya yakni menginstruksikan siswa yang telibat memainkan peran dalam sosiodrama untuk kembali pada tempat duduknya masing-masing. Kemudian peneliti dan guru BK melanjutkan kegiatan berdialog dengan siswa terkait pelaksanaan sosiodrama yang telah dimainkan. Selanjutnya, Peneliti berkolaborasi bersama guru Bk melakukan diskusi. Setelah selesai rangkaian seluruh kegiatan peneliti membagikan instrument kecanduan gadget untuk diisi sebagai Posttest.

\section{Data Kecanduan Gadget pada Siswa}

Peneliti melakukan pengambilan data sample siswa dengan membagikan instrumen kepada 50 orang siswa. Dari data 50 orang tersebut peneliti kemudian melakukan kategorisasi data penelitian dengan mencari Mean, Nilai (Max), Nilai (Min) dan Standard Deviasi.

Tabel 4. Data Mean, Nilai (Max), Nilai (Min) dan Standard Deviasi

\begin{tabular}{|c|c|}
\hline Mean & 94 \\
\hline Nilai (Max), & 126 \\
\hline Nilai (Min) & 48 \\
\hline SD & 15 \\
\hline Interval & 15 \\
\hline
\end{tabular}

$$
=72<\mathrm{M} \leq 87
$$

Untuk mencari kategorisasi peneliti menggunakan rumus Azwar (2012) sebagai berikut;

c) Sedang $(X)=M-0,5 \mathrm{SD}<\mathrm{X} \leq \mathrm{M}+0,5 \mathrm{SD}$

$$
\begin{aligned}
& =87<X \leq 94+0,5(15) \\
& =87<X \leq 102
\end{aligned}
$$

a) Sangat Rendah $(X)=\mathrm{M}-1,5 \mathrm{SD}<\mathrm{X}$

$$
\begin{aligned}
& =94-1,5(15) \\
& =72
\end{aligned}
$$

d) Tinggi $(X)=M+0,5 \mathrm{SD}<\mathrm{X} \leq \mathrm{M}+1,5 \mathrm{SD}$

$=102<\mathrm{X} \leq 94+1,5(15)$

$=102<\mathrm{X} \leq 117$

b) Rendah $(X)=M-1,5 S D<X \leq M-0,5 S D$

$$
=72<X \leq 94-0,5(15)
$$

e) Sangat Tinggi $(X)=M+1,5 S D>X$

$$
=117>\mathrm{X}
$$


Tabel 5. Kategorisasi Data

\begin{tabular}{|c|c|}
\hline Kategorisasi & Interval Nilai \\
\hline Sangat Rendah & $<72$ \\
\hline Rendah & $73-87$ \\
\hline Sedang & $88-102$ \\
\hline Tinggi & $103-117$ \\
\hline Sangat Tinggi & $\geq 118$ \\
\hline
\end{tabular}

Data dari ke 50 siswa tersebut kategorisasi Rendah dan 4 orang masuk ditemukan kategorisasi terhadap data kategorisasi Sangat Rendah. Peneliti sebagai berikut; 3 orang masuk ke kemudian mengambil 10 orang dengan kategorisasi Sangat Tinggi, 7 orang masuk nilai Tinggi dan Sangat Tinggi untuk kategorisasi Tinggi, 28 orang masuk dijadikan Sampel Penelitian.

kategorisasi Sedang, 8 orang masuk

Tabel 6. Hasil Pre-test dan Post-test

\begin{tabular}{|c|c|c|c|c|c|}
\hline No & Nama & Pre-test & Kategori & Pot-test & Kategori \\
\hline 1 & C & 125 & Sangat Tinggi & 56 & Sangat Rendah \\
\hline 2 & J & 123 & Sangat Tinggi & 57 & Sangat Rendah \\
\hline 3 & O & 126 & Sangat Tinggi & 62 & Sangat Rendah \\
\hline 4 & R & 115 & Tinggi & 42 & Sangat Rendah \\
\hline 5 & V & 110 & Tinggi & 59 & Sangat Rendah \\
\hline 6 & AF & 112 & Tinggi & 52 & Sangat Rendah \\
\hline 7 & AJ & 107 & Tinggi & 55 & Sangat Rendah \\
\hline 8 & AO & 108 & Tinggi & 44 & Sangat Rendah \\
\hline 9 & AU & 108 & Tinggi & 46 & Sangat Rendah \\
\hline 10 & D & 110 & Tinggi & 49 & Sangat Rendah \\
\hline
\end{tabular}

Sebelum dilakukan uji T-test maka adalah uji normalitas Kolmogorovdata terlebih dahulu dilakukan uji Smirnov. normalitas. Uji normalitas yang digunakan

Tabel 7. Hasil uji normalitas

\begin{tabular}{|c|c|c|c|c|}
\hline No & Variabel & D & K & Keterangan \\
\hline 1 & Pre-test & 0,22598 & $<0,40925$ & Normal \\
\hline 2 & Post-test & 0,12155 & $<0,40925$ & Normal \\
\hline
\end{tabular}

Data pada Pre-test dilihat dapat dilanjutkan dilakukan pengujian 0,22598<0,40925 yang berarti data dengan menggunakan T-test.

berdistribusi Normal dan data Post-test Data pada Pre-Test ditemukan 3 dilihat 0,12155<0,40925 yang berarti data orang masuk pada kategorisasi Sangat juga berdistribusi Normal. Setelah data tinggi kecanduan Gadget dan 7 orang ditemukan berdistribusi normal maka, data masuk pada kategorisasi Tinggi kecanduan 
Gadget. Sementara pada data Post-Test setelah melakukan layanan bimbingan kelompok dengan teknik sosiodrama ditemukan penurunan angka kecanduan dengan 2 orang masuk kategorisasi Sangat Rendah kecanduan Gadget, 7 orang masuk kategorisasi Rendah kecanduan Gadget dan 1 orang masuk kategorisasi Sedang kecanduan Gadget. Setelah didapatkan nilai Pre-Test dan nilai Post-test, maka dilakukan pengujian tingkat signifikansi antara nilai pre-test dan nilai post-test. Penelitian ini menggunakan Uji $\mathrm{T}$ dalam pengujian hipotesisnya. Analisis tersebut digunakan untuk mengetahui tingkat Berdasarkan perhitungan uji T-test moment dengan menggunakan bantuan program MS. Excel diperoleh nilai signifikan. Hal ini menunjukan adanya hubungan yang signifikan antara bimbingan kelompok teknik sosiodrama dengan kecanduan gadget. $\mathrm{t}$ (hitung)= 19,561 kemudian dibandingkan dengan $t$ $($ table $)=2,1009022$. Dengan demikian 19,561 $>2,1009022$. Maka kesimpulan yang dapat ditarik dari penelitian ini adalah layanan bimbingan kelompok dengan teknik sosiodrama dapat mengurangi kecanduan gadget pada siswa Madrasah Aliyah Swasta (MAS) Al - Washliyah Tembung.

\section{PEMBAHASAN}

Data pada Pre-Test ditemukan 3 orang masuk pada kategorisasi Sangat tinggi kecanduan Gadget dan 7 orang masuk pada kategorisasi Tinggi kecanduan Gadget. Sementara pada data Post-Test setelah melakukan layanan bimbingan kelompok dengan teknik sosiodrama ditemukan penurunan angka kecanduan dengan 2 orang masuk kategorisasi Sangat Rendah kecanduan Gadget, 7 orang masuk kategorisasi Rendah kecanduan Gadget dan 1 orang masuk kategorisasi Sedang kecanduan Gadget. Hal ini menunjukkan signifikansi antara variabel $\mathrm{x}$ (layanan bimbingan kelompok teknik sosiodrama) terhadap variabel y (kecanduan gadget), apakah hipotesis dapat diterima atau ditolak.

Adapun kriteria pengambilan keputusan dengan cara melakukan perhitungan uji signifikansi cara membandingkan nilai pre-test dan posttest. Jika nilai signifikasi $<0,05$ maka maka Ho diterima dan Ha ditolak. Tetapi sebaliknya apabila nilai signifikasi $>0,05$ maka Ha diterima dan Ho ditolak. Dari perhitungan dengan bantuan program $M$ s. Excel diperoleh hasil berdasarkan hasil kategorisasi penelitian ini menunjukkan hasil bahwa ada pengurangan tingkat kecanduan Gadget ayng siginifikan ditinjau dari segi kategorisasi.

Layanan konseling dinilai sangat bermanfaat dalam mereduksi prilakuperilaku negative pada siswa sebagaimana halnya melalui layanan konseling mampu merubah prilaku menjadi lebih baik dengan cara meningkatkan pemahaman akan diri dan menciptakan kemandirian pada siswa (Fauza, W., \& Chalidaziah, W. (2021; Sari, I. M., \& Prajayanti, E. D. 2017).

Pada saat menggunakan gadget, waktu mereka terbuang untuk terus bermain game yang dilakukan berulangulang dan menimbulkan dampak negatif begitupun dengan kecanduan terhadap gadget (Asirotul, M., \& Naning, P.S. 2019). Hal ini akan menghambat proses sosialisasi anak dan akan menimbulkan ketergantungan pada gadget tersebut. Hal ini menjelaskan bahwa kecanduan pada gadget dapat menyebabkan anak dapat menimbulkan dapat negatif yang dapat menyebabkan anak mengalami hambatan sosialisasi. Gadget juga ternyata secara efektif dapat mempengaruhi pergaulan sosial anak terhadap lingkungan terdekatnya. 
Disamping itu orang tua harus mampu menjadi guru bagi anaknya. Gadget dijadikan media untuk menstimulasi anak. Misalnya, fitur-fitur yang sesuai dengan anak (Permainan) bisa dikembangkan untuk bahan diskusi supaya anak tidak terlalu fokus pada Gadgetnya, dengan penerapan seperti itu anak dilatih untuk tetap berinteraksi dengan lingkungan sekitarnya.

\section{KESIMPULAN}

Adapun kesimpulan yang diproleh berdasarkan ekperiment ini yaitu secara keseluruhan kecanduan gadget pada siswa sebelum diberikan perlakuan berupa bimbingan kelompok dengan teknik sosiodrama berada dalam kategori tinggi. Dan setelah ekperiment dilakukan terdapat perubahan signifikan berupa pada kecanduan penggunaan gadget yang menurun menjadi sangat rendah. sehingga setelah dianalisis hasil eksperimen bimbingan kelompok dengan teknik sosiodrama dikatatakan efektif dalam menurunkan kecanduan gadget pada siswa.

\section{DAFTAR PUSTAKA}

Armayanti, L. 2013. Pengaruh Kecanduan Gadget terhadap Kemampuan Bersosialosasi pada Remaja. Jurnal An- Nafs. Vol. 8. No. 2.

Asirotul, M., \& Naning, P.S. (2019). Reduce the of Gadgets: Parent's Coping Strategies for Childreen's Social Development. International Journal of Nursing and Midwifery Science ( I JNMS), Vol. 3

Darnoto, A. R. P. (2016). Hubungan Penggunaan Smartphone dengan Perilaku Seksual Remaja di SMAN " $X$ " Jember. Universitas Jember.

Faiz, N. (2018). Pengaruh Intensitas Anak Mengakses Gadget dan Tingkat
Saran

Adapun saran yang dapat diberikan setelah melakukan penelitian adalah sebagai berikut;

1. Guru bimbingan dan Konseling dapat menjadikan bimbingan kelompok dengan teknik sosiodrama sebagai salah satu layanan di sekolah untuk mengurangi kecanduan gadget pada siswa.

2. Siswa menjadi orang yang lebih baik dan dapat mengurangi kecanduan gadget yang sebelumnya terjadi dengan mengikuti bimbingan kelompok dengan teknik sosiodrama dengan bersungguh-sungguh.

3. Sekolah mendapat alternative solusi dalam mengentaskan permasalahan siswa yang mengalami kecanduan gadget pada siswa

4. Peneliti lain dapat menjadikan penelitian ini sebagai bahan refrensi untuk melakukan penelitian sejenis dengan tindakan maupun dengan metode penelitian yang sama.

Kontrol Orang Tua Anak terhadap Interaksi Sosial Anak SD Kelas Tinggi Di SD 1 Pasuruhan Kidul Kudus Jawa Tengah: Elmentary School Vol 5 (1)

Fauza, W., \& Chalidaziah, W. (2021). Konseling Individual dalam Mengatasi Perilaku Agresif Siswa. Syifaul Qulub: Jurnal Bimbingan Dan Konseling Islam, 2(1), 43-52.

https://doi.org/10.32505/syifaulqulu b.v2i1.3236

Prayitno dan Amti, E. (2004). Dasar-dasar Bimbingan dan Konseling. Jakarta: Rineka Cipta 
Rochmawati ,R. (2012). Penerapan Metode Sosiodrama dalam Pembelajaran Aqidah Akhlak pada Siswa Kelas VII di SMP Islam Raden Paku Surabaya. Skripsi. Surabaya: IAIN Sunan Ampel

Rosy, B. (2017). Sociodrama Method; Stimulate the Development of Attitudes, Knowledge and Skills of Students in Excellent Service Learning. Jurnal Pendidikan Bisnis dan Manajemen, 3 (1), 25 - 34

Sari, I. M., \& Prajayanti, E. D. (2017). Peningkatan Pengetahuan Siswa SMP tentang Dampak Negatif Game Online bagi Kesehatan. Gemassika, 1(2), 31- 39.

Susanto. A. (2018). Bimbingan dan Konseling di Sekolah: Konsep, Teori, dan Aplikasinya. Jakarta: Prenada Media Group.

Viega, S. (2015). Sociodrama in the Training of Social Educators An Exploratory Research. The Journal of Psychodrama, Sociometry, and Group Psychotherapy, Vol. 63. No. 1. 47-64 DOI: 10.12926/0731-1273-63.1.47.

Winkel W.S, Hastuti, S. (2006). Bimbingan dan Konseling di Institusi Pendidikan. Yogyakarta: Media Abadi

Yulia, T. (2015). Pengaruh Penggunaan Gadget terhadap Perkembangan Psikososial Anak Usia Prasekolah (3-6 Tahun) di TK Swasta Kristen Immanuel Tahun Ajaran 2014-2015.

Yuwanto. L. (2012). Development of Mobile Phone Addict Scale. Anima Indonesian Psychological Journal, 27 (4), 211-222 